\title{
Evaluation of Anti-Helicobacter pylori IgG in Sera of Pregnant Women
}

\author{
Samir Abdul Amir Abid Ali Alash \\ Department of Biology, College of Science, University of Baghdad.
}

\begin{abstract}
Helicobacter pylori is a bacterial infection of the stomach, which plays a major role in abdominal symptoms and gastroduodenal pathology. The pregnant women had a significantly higher relative risk of acquiring $\mathrm{H}$.pylori infection during pregnancy as a result of physiological alterations. To investigate the relationship of H.pylori with dyspeptic symptoms in early and late pregnancy, thirty sera samples were obtained from pregnant women and thirty sera samples were obtained from apparently healthy women as control. All studied groups were evaluated antiHelicobacter pylori IgG antibody by ELISA. Ten of pregnant women samples $(33.3 \%)$ were seropositive of anti-H. pylori IgG antibody in pregnant women compared with control. This lead to suggest that $H$. pylori positive may be related to nausea and vomiting in pregnant women.
\end{abstract}

Keywords: Helicobacter pylori, Helicobacter pylori IgG, Immunoglobulin G, ELISA.

\section{Introduction}

Helicobacter pylori is one of the most common bacteria infecting human in the world and it infects children in the developing countries early in life [1]. The prevalence of $H$. pylori is closed tied to socioeconomic condition and accordingly, this infection is more common in developing countries than in other countries such as united state [2]. There was a relationship between $H$. pylori infection and anemia in pregnant women, therefore, the tests for $H$. pylori infection be included in preconception consultations, especially for women who have a history anemia or persistent anemia [3]. H. pylori infection during pregnancy sent to be interfering with trace elements metabolism and can promote significantly to increase morbidity. Prior to confirmation of these findings in a wellcontrolled woman to be screened for $H$. pylori infection to reduce $H$. pylori associated during pregnancy [4]. Pregnancy has been associated with changes in both humoral and cellular immunity, these changes included alternative in the various classes of antibodies during differential gestational periods. These alternations may expose pregnant women to an increase risk of infection with microorganisms [5]. Infection with cag A, positive $H$. pylori strain is linked to an increase in women potential to abort early possible through increase released of inflammatory cytokines [6].

\section{Materials and Methods}

All samples were collected and measured in a private laboratory in Al-Karrada AlSharqia city. The study included thirty pregnant women with age $22-35$ years and thirty non-pregnant women as control. All studied groups were measured anti- $H$. pylori IgG antibodies by ELISA test from Euroimmune (Germany) [7].

\section{Results and Discussion}

The result of anti- $H$. pylori $\operatorname{IgG}$ antibody showed that there were significant differences $(\mathrm{P} \leq 0.05)$ between studied groups.

In comparison with control, 10 of thirty pregnant women samples (33.3\%) (Fig. (1)) had seropositive of $H$. pylori IgG antibody. 


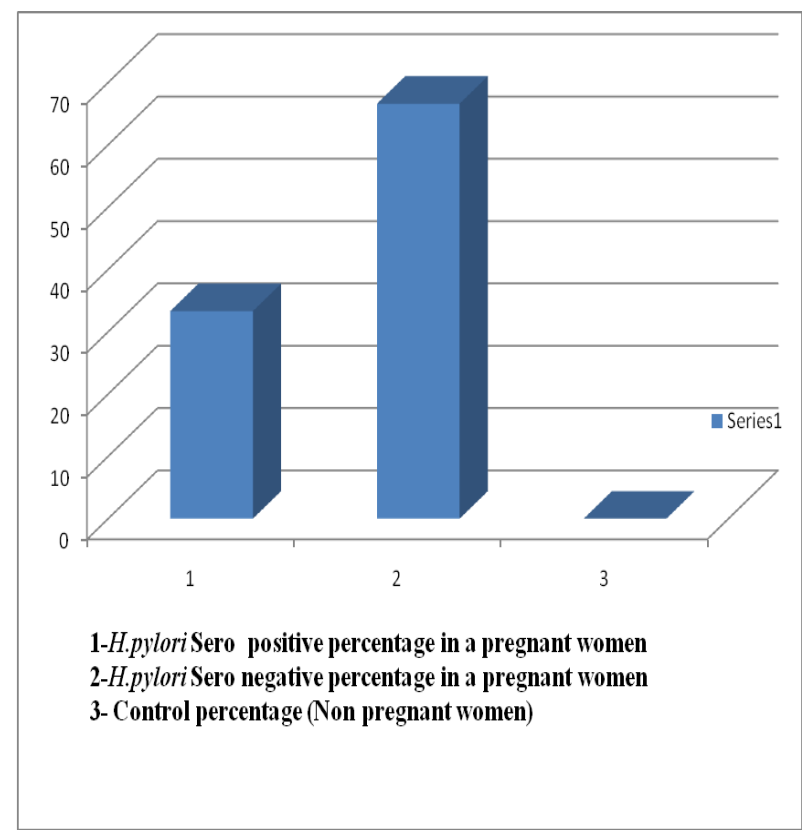

Fig. (1) H. pylori in studied groups.

H. pylori sero prevalence in French pregnant women decreased from $18.7 \%$ to $11.2 \%$ which is agreement with decrease $H$. pylori in other western European countries [8].

In another study showed that $H$. pylori is not associated with an increase in dyspepsia or with maternal or non-maternal morbidity [9]. H. pylori seropositive varies with geographic origin. The Percentage incidence of Infection with $H$. pylori in Finland reaches 10\% [10], $15.5 \%$ in Belgium [11] and $44.8 \%$ in Turkey [12]. H. pylori is associated with nausea and vomiting [13]. Pregnancy is a physiological condition associated with both anatomical and biochemical alternation. All geared towards the sustenance of the growing fetus [14]. Hyperlipidemia which is a common feature of both pregnancy and $H$. pylori infection is a known risk factor for coronary heart disease [15]. Others showed that pregnant women with H. pylori may have increased disorder in lipid metabolism than non-infected pregnant women [16].

\section{Conclusions}

This study is compatible with other studies which reviewed that H.pylori infection in pregnant women could be plays an important role in causing functional dyspepsia. It commonly causes symptoms such as nausea, vomiting, abdominal pain, and bloating [17], [18], [19].

\section{References}

[1] Basily, S.R.; Freack, E.W.; Moharch, T. "Seropositive of $H$. pylori among Egyptian newborn and their mothers". A preliminary report. Americ. J. Trop. Med. Hyg., 61:37 - 40, 1999.

[2] Everhart, J.E. "Recent development in the epidemiology of $H$. pylori". Gastroenter Clin. N. Americ., 29:559-578, 2000.

[3] Dolatian, M.; Noori, R.; Zojagy, H. and Majd, H. "Relationship between $H$. pylori infection and anemia in pregnant women". J. Rep. Infer., 8(3), 2007.

[4] Ugwuja, E.I. "Impact of maternal H. pylori infection on trace element (copper, iron, zinc) and pregnancy". J. Health and Allied Sciences, 8(4): 1 - 7, 2010.

[5] Lanciers, S.; Despinsse, B.and Metha, D. "Increased susceptibility to $H$. pylori infection in pregnancy". Infect Dis. Obstetcynecol., 7(4): 195 - 198, 1999.

[6] Hajishafiha, M.; Ghasemi, M.; Memari, A. and Naji, S. "Effect of $H$. pylori infection on pregnancy rates and early pregnant loss after intracytoplasmic sperm injection". Inter. J. Women Health, 3: $329-335$, 2011.

[7] Lequin $\mathrm{R}$ "Enzyme immunoassay (EIA)/enzyme-linked immunosorbent assay (ELISA)". Clin. Chem. 51 (12): 2415-8. (2005).

[8] Kalach, N.; Desrame, J.; Bonnet, C. and Raymond, J. " $H$. pylori seroprevalence in asymptomatic pregnant women in France". Clin. Vaccine Imol., 9(3): 736 - 737, 2002.

[9] Mackenna, D.; Watson, M. and James, D. " $H$. pylori infection and dyspepsia in pregnancy". Obstetrics and Gynecology, 102(4): 845 - 849, 2003.

[10] Ashon, M.; Meittinen, T.; Ruuska, P. and Laippala, M. "Sero epidemiological study of $H$. pylori infection in infancy". Arch. Dis. Child. Fetal, 74:141 - 142, 1996.

[11] Blecker, U.; Lanciers, S. and Vandenpals, Y. "The prevalence of $H$. pylori positivity in a symptom-free population aged 1 to 40 years". J. Clin. Epidemiol., 47:1095 1098, 1994.

[12] Kocak, I.; Akcan, Y.; Ustun, C. and Demirel, L. " $H$. pylori seropositive in patients with hyperemesis gravidarum". Int. J. Gynecol., 66: 251 - 254, 1999. 
[13] Quinlan, J. and Hill, D. "Nausea and vomiting of pregnancy". Am. Family Physican, 68: 121 - 128, 2003.

[14] Ajose, O.A.; Fasuba, O. and Thomas, K. "Serolipid and lipoprotein cholesterol profile in pregnant Nigerian Women". J. Clin. Sci., 2(1): 9 - 13, 2002.

[15] Shankar, V.; Demitas, B.and Daniya, K. "Comparision of fasting and postprandial lipid profile in patients of Coronary heart disease". Bombay. Hosp. J., 50(3): 445 449, 2003.

[16] Ugwuja, E. and Ugwn, N. "Plasma lipid in H. pylori infected pregnant women". Int. J. Med. Med. Sci., 1(5): 224 - 226, 2009.

[17] Alvaro Reymunde, Nilda Santiago and Lianette Perez. "Helicobacter pylori and severe morning sickness". The American Journal of Gastroenterology, 96:22792280, 2001.

[18] Philip, B. "Hyperemesis gravidarum: Literature review". WMJ, 102:46-51,2003.

[19] Debra, S. Penney. "Helicobacter pylori and severe nausea and vomiting during pregnancy". J. Midwifery and Women's Health., Vol.50,Issue 5: 418-422, 2005.

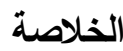

تعد بكتريا H.pylori احد انواع اصابات المعدة والتي

تلعب دورا رئيسيا في اعراض البطن والامراض المعدية. تكتسب النساء الحوامل خطر الاصابة بهذه البكتريا كنتيجة الى التغيرات الفسيولوجية الحاصلة لديهم. لأجل التحري في مدى علاقة H.pylori مع اعراض عسر الهضم لدى النساء

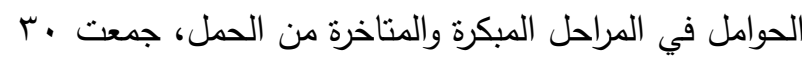

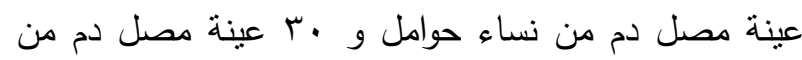

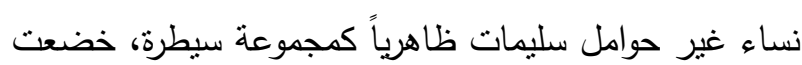

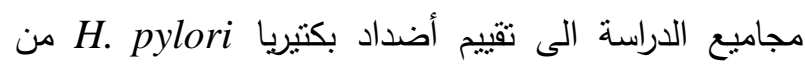
النوع IgG بأستخدام إختبار ELISA حيث أظهرت الدراسة

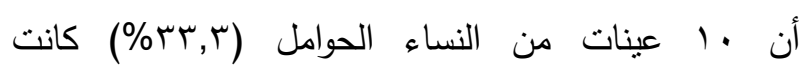
مصولهن أيجابية لبكتيريا H. pylori. يمكن الأستنتاج من من الناء وجود أضداد بكتيريا H. pylori من النوع IgG في مصول النساء الحوامل ان له علاقة بأصابتهن بالغثيان والقيء. 